HSTC Bulletin

Journal of the History of Canadian Science, Technology and Medecine

hstc

Revue d'histoire des sciences, des techniques et de la médecine au Canada

bulletin

\title{
Recent Publications Publications récentes
}

Volume 4, numéro 2 (14), february 1980

URI : https://id.erudit.org/iderudit/1081533ar

DOI : https://doi.org/10.7202/1081533ar

Aller au sommaire du numéro

Éditeur(s)

HSTC Publications

ISSN

0228-0086 (imprimé)

1918-7742 (numérique)

Découvrir la revue

Citer ce document

(1980). Recent Publications. HSTC Bulletin, 4(2), 7-9.

https://doi.org/10.7202/1081533ar

All Rights Reserved ( C Canadian Science and Technology Historical Association / Ce document est protégé par la loi sur le droit d'auteur. L’utilisation des Association pour l'histoire de la science et de la technologie au Canada, services d’Érudit (y compris la reproduction) est assujettie à sa politique d'utilisation que vous pouvez consulter en ligne.

https://apropos.erudit.org/fr/usagers/politique-dutilisation/ 
The Dean of Applied Science at Queen's who supported the Pilot Project should be commended. Richardson does not name him. However, for the record, we should know that he was Dr. Robert J. Uffen. Not only do we need more Richardsons in Canada, we need more Uffens:

In his report, Richardson speaks of the problems involved in getting those knowledgeable about inventory items to tell their stories. He describes these problems sympathetically, not critically. Quite recently, I experienced at first hand the interview conducted by one of my family with the owners of a heritage house and the enthusiasm that built up as they described the 120-year development of the structure and its contents. Such enthusiasm is the result of attention being paid to heritage houses. I hope that the work of George Richardson and his 1979 team will help to foster a heritage-type of enthusiasm in more districts of Eastern Canada - and even in the West! Here, perhaps, is something the Engineering Institute Committee can do right away.

- Andrew H. Wilson

Ottawa

RECENT PUBLICATIONS RECENTES

Agriculture:

Graeme Wynn, "Late Eighteenth-century Agriculture on the Bay of Fundy Marshlands," Acadiensis 8:2 (Spring 1979), 80-9.

Aviation:

James Dow, The Arrow. Toronto: James Lorimer, 1979.

Larry Milberry. Aviation in Canada. Toronto: McGrawHill-Ryerson, 1979.

Bibliography/Bibliographie :

Duncan Kent, British Columbia: A Bibliography of Industry, Labour, Resources $\underline{\text { Regions }} \overline{\text { for the Social sciences. }}$ Vancouver: UBC Press, 1978.

Scientific Policy, Research and Development in Canada/La Politique des sciences, la recherche et le developpement au Canada--Supplement (1977-79). Ot tawa: NRC, $19 \overline{79}$.

Unzon List of Scientific Serials in Canadian Libraries/ Catalogue collectif des publications scientifiques dans les bibliotheques canadiennes. 8 ed., 2 vols. ottawa: N $\overline{R C}, 1979$. 
Biography/Blographie:

"The Menten Plaque," Bul. Can. Biochem. Soc. 16:2 (Nov 1979). (on Canadian-born enzymologist Maud Menten).

Wilder Penfield No Man Alone: A Neurosurgeon's Life. Boston: Lit $\overline{\text { IIe}}, \bar{B}$ rown, $19 \overline{7} 7$.

Crafts/Métiers:

David I. Newlands. Early Ontario Potters: Their Craft and Trade. Toronto: McGraw-

David L. Newlands. The New Hamburg Pottery, New Hamburg,

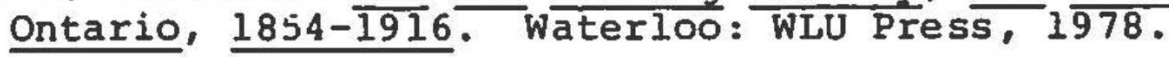

Exploration:

Special Issue: Captain James Cook: Man, Myth and Reality. Pacific Studies 1:2 (Spring 1978).

Industries :

Francine Adam-Villeneuve. Les Moulins à eau de la vallée du Saint-Laurent. Montréal: Editions de $\overline{I^{\prime}}$ Homme, 1978 .

Doug Baldwin and John Dunn. Cobalt: A Pictorial History of the Development of silver Miñing. Cobalt: Highway Bookshop, 1976 .

Marcel Moussette, La Pêche sur le Saint-Laurent: Répertoire des methodes et des engins de capture. Montreal: Editions Boréal Express, 1979.

R.H. Sherwood, "Discovery of Kerosene," Nova Scotia Historical Quarterly 9:2 (June 1978), 157-64.

\section{Institutions:}

N.T. Gridgeman. Biological Sciences at the National Research Council of Canada: The Early Years to 1952. Waterloo: WLU Press, $1 \overline{979}$

Charles Sankey. PAPRICAN: The First Fifty Years. Pointe claire: Pulp and Paper Research Institute of Canada. 1976

Medicine/Médecine:

Charles M. Godfrey. Medicine for Ontario: A History Belleville: Mika, 1979. 
Transportation:

Gordon Bennett. Yukon Transportation: A History Ottawa: Indian and Northern Atfairs $\bar{s}, 1978$.

P.C. Dorin.. The Grand Trunk Western Railroad: A Canadian National Railway. Seattle: Superior, 1977.

Norman Helm. History of the Ontario Northland Railway. Cheltenham: Boston Mills Press, 1979.

Norman Helm. Tri-Town Trolleys. Cheltenham: Boston Mills Press, 1979. (on Nipissing Railway)

J. and L. Payzant. Like a Weaver's Shuttle. Halifax: Nimbus, 1979. Ton Hālifax-Dartmouth ferries).

James Plomer. Desperate Venture: The Story of the Central Ontario Railway. Belleville : Mika, $197 \overline{9}$.

Albert Tucker. Steam into Wilderness: Ontario Northland Railway, 1902-19 $\overline{62}$. Toronto: Fitzhenry and Whiteside, 1978 . 